\title{
SOCIODEMOGRAPHICAL AND CLINICAL PRESENTATION OF TRAUMATIC BRAIN INJURY PATIENTS
}

\author{
MONDOL MA ${ }^{1}$, RAHMAN N ${ }^{2}$, AKHTER $\mathrm{S}^{3}$, AHMED B ${ }^{4}$, RAHMAN A ${ }^{5}$, MOMEN MA ${ }^{6}$, RAHMAN M ${ }^{7}$, \\ TALUKDER DC 8
}

\begin{abstract}
Background: Traumatic brain injury (TBI) is a non degenerative, non congenital insult to the brain from an external force, possibly leading to permanent or temporary impairment of cognitive, physical and psychosocial functions with association of diminished and altered state of consciousness. It accounts for approximately $40 \%$ of all deaths from acute injuries in the united state. Twenty percent of TBI occurs in the paediatric age young people and men aged about 15-30 are the high risk of population. The study is to define TBI appropriately, to know the causes of TBI, clinical presentations and severity of TBI patients in our hospital.

Methods: A direct observational study was carried out from $18^{\text {th }} \mathrm{July}, 2010$ to $31^{\text {st }}$ December, 2010. Total numbers of patients were 100. A semi structured pretest questionnaire was used to take proper history, clinical assessment, their management and programs.

Results: A total of 100 patients with traumatic brain injury (TBI) in which $84 \%$ were male and $16 \%$ were female. Out of 100 patients irrespective of sex it was observed that most patients that is $26 \%$ belongs to age group 26-35yrs then $24 \%$ belongs to age group 16-25yrs. Out of 100 patients $48 \%$ was RTA (Road traffic accident) then 28\% was assault and $22 \%$ belongs to fall in. Out of 100 patients it was observed that most presenting complaints was unconscious $42 \%$, headache $36 \%$ and vomiting $26 \%$, mental functions i.e. unconscious $42 \%$ and $36 \%$ belongs to normal. $42 \%$ showed impaired motor and $20 \%$ sensory. $62 \%$ complaint unable to walk. Bladder dysfunction belongs to $64 \%$.

Conclusion: Traumatic brain injury accounts $40 \%$ of all death from acute injuries in the developed country. This percentage is now increasing in developing country like Bangladesh. So government and private organizations should setup more trauma centre and can enhance to decrease the adverse conditions.
\end{abstract}

J Dhaka Med Coll. 2013; 22(1) : 45-50.

\section{Introduction:}

Traumatic brain Injury (TBI) is a non degenerative, non congenital insult to the brain from an external force, possibly leading to permanent or temporary impairment of cognitive, physical and psychosocial functions with an associated diminished and altered state of consciousness. ${ }^{1}$

The Annual incidence of TBI requiring hospitalization and overall is estimated to be 200 and 500 cases respectively; 10, 00000 population in the USA with approximately 1-4

1. Dr. Muhammed Alamgir Mondol, Honorary Medical Officer, Department of Physical Medicine \& Rehabilitation, Bangabandhu Sheikh Mujib Medical University (BSMMU), Dhaka.

2. Dr. Nadia Rahman, Medical Officer, Department of Physical Medicine \& Rehabilitation, Bangabandhu Sheikh Mujib Medical University (BSMMU), Dhaka.

3. Dr. Shohela Akhter, Associate Professor, Department of Paediatrics, Bangabandhu Sheikh Mujib Medical University (BSMMU), Dhaka.

4. Dr. Badrunnesa Ahmed, Medical Officer, Department of Physical Medicine \& Rehabilitation, Bangabandhu Sheikh Mujib Medical University (BSMMU), Dhaka.

5. Dr. Azizur Rahman, Assistant Surgeon, Sadar Hospital, Kishoregonj.

6. Dr. Md. Abdul Momen, Associate Professor, Department of Surgery, Rajshahi Medical College, Rajshahi.

7. Dr. Mahmudur Rahman, Assistant Professor, Department of Physical Medicine \& Rehabilitation, Bangabandhu Sheikh Mujib Medical University (BSMMU), Dhaka.

8. Dr. Debesh Chandra Talukder, Assistant Professor, Dept. of ENT, Dhaka Medical College

Correspondence: Dr. Shohela Akhter, Associate Professor, Department of Paediatrics, Bangabandhu Sheikh Mujib Medical University (BSMMU), Dhaka. E-mail: drzharna@gmail.com 
million receiving urgent care. ${ }^{2-8}$ The remaining $20 \%$ of the hospitalized new injuries can be evenly divided between moderate and severe injuries. ${ }^{9,} 10$ Male are 1.5 times as likely to sustain and 3 to 4 times more likely to be die from a TBI. 5, 6, 7,8,11

TBI accounts for approximately $40 \%$ of all deaths from acute injuries in the United States. Twenty percent of TBI occurring in the paediatric age among children must (i.e. birth to 17 th) ${ }^{7} 0-14$ yrs. In an estimated 475000 TBIS occurs each year. ${ }^{11}$ Young people and men aged about $15-30$ are the high risk population. ${ }^{12}$

TBI is caused by a severe jolt or blow to the head or a head injury that penetrates and disrupts normal brain function. ${ }^{5,} 6$ Alcohol abuse is the largest indirect cause of TBI. ${ }^{13,14}$ Autopedestrian and bicycle crashes are most common among the children while falls $\left(28^{\text {th }}\right)$ are most common both children and older adult. $3,5,7,14,15$ Motor vehicle accident $(20 \%)$ is the highest among people aged up to 15 to 19 years.

TBI signs and symptoms may sometimes be subtle and might not appear for days or weeks after injury. Some patients may look well, even though they may feel or behave differently. ${ }^{16}$ Our brain controls our movements, thought, sensations and behaviors. A TBI can have several different physical and psychological effects. Initial physical effects are bruising and swelling. When injured brain tissue swells up pressure is increased; the injured brain tissue presses against the skull causing additional damage. ${ }^{17,18}$ Rationale of study to define TBI properly, to know causes of TBI, clinical presentations and severity of TBI patients in our hospital.

\section{Methods:}

This direct observational study was performed in department of physical medicine and rehabilitation, Bangabandhu Sheikh Mujib Medical University (BSMMU) and Department of Neurology, Dhaka Medical College Hospital, Dhaka, from $1^{\text {st }}$ July 2010 to $31^{\text {st }}$ December 2010.
A total of 100 patients were included in the study who have traumatic injury with or without injury to the skull or scalp injury aged 5-75yrs. Any patient who has $\mathrm{H} / \mathrm{O}$ cardiovascular disease (CVD) and congenital neurological disease is excluded in this study.

\section{Assessment and study method:}

All the patients were studied with proper history, clinical assessment, their management and prognosis. The data was compiled and coded properly. Numerical data was analyzed statistically.

\section{Ethical consideration:}

In the study, the subjects were informed about the nature of the study and written consent was taken. No drugs and other medication were used for trial.

\section{Observations and results:}

A total of 100 patients with traumatic brain injury were ultimately included in the study. Eighty four among them were male and sixteen were female. Male to female ratio was 5.25:1. Percentage of male and female were 84 and 16 respectively. Sex distribution of these patients is shown in (Table No. I). The age range of patients in the study varied from aged 5 to 70 years in respective of both sex. Out of 100 patients irrespective of sex it was observed that most patients that is $26(26 \%)$ belongs to age group of 26-35 years, then 24 (24\%) belongs to age group of 16-25 years, then 14 (14\%) belongs to age group of $36-45$ years, then $12(12 \%)$ belongs to age group of 5-15 years, then 10 (10\%) belongs to age group of 46-55 years (Table no. I). Out of total 100 patients $26(26 \%)$ which is most in number were cultivator, then $22(22 \%)$ which belongs to day labour group, then $14(14 \%)$ which belongs to student, then $12(12 \%)$ which belongs to house wife and service holder (Table no. I). Among 100 patients 54\% which are most in number were lower class, then $22 \%$ which belongs to lower middle class, then $14 \%$ which belongs to upper middle class and 10\% which belongs to upper class (Table-I). 
Table-I

Distribution of sex/age/Occupation/ socioeconomic conditions $n=(100)$

\begin{tabular}{|c|c|c|}
\hline & $\begin{array}{c}\text { No. of } \\
\text { patient }\end{array}$ & $\begin{array}{c}\text { Percentage } \\
(\%)\end{array}$ \\
\hline \multicolumn{3}{|l|}{ Sex } \\
\hline Male & 84 & 84 \\
\hline Female & 16 & 16 \\
\hline Age group (years) & $05-15$ & 12 \\
\hline \multicolumn{3}{|l|}{12} \\
\hline $16-25$ & 24 & 24 \\
\hline $26-35$ & 32 & 32 \\
\hline $36-45$ & 14 & 14 \\
\hline $46-55$ & 10 & 10 \\
\hline $56-65$ & 02 & 02 \\
\hline$>66$ & 06 & 06 \\
\hline \multicolumn{3}{|l|}{ Occupation } \\
\hline Cultivator & 26 & 26 \\
\hline Day labour & 22 & 22 \\
\hline Student & 14 & 14 \\
\hline Service holder & 12 & 12 \\
\hline House wife & 12 & 12 \\
\hline Businessman & 10 & 10 \\
\hline Others & 04 & 04 \\
\hline \multicolumn{3}{|c|}{ Socioeconomic condition } \\
\hline Lower class & 54 & 54 \\
\hline Lower middle class & 22 & 22 \\
\hline Upper middle class & 14 & 14 \\
\hline Upper class & 10 & 10 \\
\hline
\end{tabular}

Out of total 100 patients $48 \%$ which is most in number were RTA, then $28 \%$ which belongs to assault, then $22 \%$ which belongs to fall and then $2 \%$ which belongs to others (Table no. II). Among 100 patients the most presenting complaints was unconsciousness $42 \%$, headache $36 \%$, vomiting $26 \%$, fatigue $24 \%$, and confusion $22 \%$ (Table-II).
Table II

Causes and distribution of presenting complaints $n=(100)$

\begin{tabular}{lcc}
\hline & $\begin{array}{c}\text { No of } \\
\text { patient }\end{array}$ & $\begin{array}{c}\text { Percentage } \\
(\%)\end{array}$ \\
\hline Causes & 48 & 48 \\
RTA & 28 & 28 \\
Assault & 22 & 22 \\
Fall & 02 & 02 \\
Others & & \\
Complaints & 42 & 42 \\
Unconsciousness & 36 & 36 \\
Headache & 26 & 26 \\
Vomiting & 24 & 24 \\
Fatigue & 22 & 22 \\
Confusion & 08 & 08 \\
Bleeding from ear & 06 & 06 \\
Neck pain & 06 & 04 \\
Bleeding from nose & 04 & 04 \\
Bleeding from eye & 04 & 02 \\
Haematuria & 02 & \\
\hline
\end{tabular}

Out of 100 patients 64\% which is most in number were impaired mental function (unconsciousness $42 \%$ and confusion $22 \%$ ), $36 \%$ which belongs to intact (Table no. III). Out of 100 patients $42 \%$ was not evaluated due to unconsciousness, $14(24.13 \%)$ which is most in number were aphasia, then $10(17.24 \%)$ which belongs to dysrthria, then 06(10.34\%) which belongs to Apraxia and $42 \%$ which is most in number was impaired motor function, 58\% which belongs to intact (Table no. III). Out of total 100 patients $64 \%$ was not evaluated due to unconsciousness $(42 \%)$ and confusion $(22 \%)$. $22(61 \%)$ which is most in number was impaired sensory function, 14 (38.89\%) which belongs to intact and out of total 100 patients $12(12 \%)$ had spinal fracture, $8(8 \%)$ had limb fracture and remaining $80(80 \%)$ were normal oriented. (Table no. III). $62 \%$ which is most in number was unable to walk due to unconsciousness $(42 \%)$, spinal fracture $(12 \%)$ and limb fracture (8\%), able to walk was $38 \%$ and $64 \%$ which is most in number was impaired bladder functions (Table-III). 
Table III

Signs of TBI $n=(100)$

\begin{tabular}{|c|c|c|}
\hline & $\begin{array}{c}\text { No of } \\
\text { patient }\end{array}$ & $\begin{array}{c}\text { Percentage } \\
(\%)\end{array}$ \\
\hline \multicolumn{3}{|l|}{ Mental functions } \\
\hline Impairment & 64 & 64 \\
\hline Intact & 36 & 36 \\
\hline \multicolumn{3}{|c|}{ Speech and language disorder } \\
\hline Aphasia & 14 & 24.13 \\
\hline Dysarthria & 10 & 17.24 \\
\hline Apraxia & 06 & 10.34 \\
\hline Intact & 28 & 48.28 \\
\hline \multicolumn{3}{|l|}{ Motor functions } \\
\hline Impairment & 42 & 42 \\
\hline Intact & 58 & 58 \\
\hline \multicolumn{3}{|l|}{ Sensory functions } \\
\hline Impairment & 22 & 61 \\
\hline Intact & 14 & 38.89 \\
\hline \multicolumn{3}{|l|}{ Fractures } \\
\hline Spinal fracture & 12 & 12 \\
\hline Limb fracture & 08 & 08 \\
\hline Intact & 80 & 80 \\
\hline \multicolumn{3}{|l|}{ Gait disorder } \\
\hline Unable to walk & 62 & 62 \\
\hline Able to walk & 38 & 38 \\
\hline \multicolumn{3}{|l|}{ Bladder function } \\
\hline Impairment & 64 & 64 \\
\hline Intact & 36 & 36 \\
\hline
\end{tabular}

Out of total 100 patients $36 \%$ which is most in number were mild, then $50 \%$ which belongs to moderate, then $10 \%$ which belongs to severe and then $4 \%$ which belongs to very severe (Table no. IV).

Table IV Severity of TBI by GCS scale $n=(100)$

\begin{tabular}{lcc}
\hline Grading & GCS & Percentage (\%) \\
\hline Mild & $13-15$ & 36 \\
Moderate & $09-12$ & 50 \\
Severe & $06-08$ & 10 \\
Very severe & $03-05$ & 04 \\
\hline
\end{tabular}

\section{Discussion:}

Traumatic Brain Injury in detail history and examination should be taken promptly in all age group of people. The assessment of TBI is fundamental to diagnosis, investigation, treatment and rehabilitation. Severity of TBI is typically determined by the initial scores on the Glasgow Coma Scale (GCS), a 15-point scale assessing eye opening, verbalization and command following. ${ }^{19}$ An individual who has sustained a mild TBI had an immediate period of altered or loss of consciousness, with GCS score of 13-15 by 30 min post injury. Moderate TBI signifies an immediate period of altered or loss of consciousness for more than $30 \mathrm{~min}$ and less than 6 hours GCS score of 9-12. Severe TBI signifies an immediate loss of consciousness without remaining consciousness for more than 6hrs (GCS score 3-8). ${ }^{20}$ In this study we found, severity of TBI by using GCS scale. Mild (13-15) was 50\%, moderate $(9-12)$ was $36 \%$, severe $(6-8)$ was $10 \%$ and very severe (3-5) was 4\%. From these study moderate TBI patients was more than mild and severe TBI because of many patients with mild TBI may not present to the hospital and the ones who do present may be discharged at the emergency department (ED) without adequate documentation. Severe TBI with associated death at the scene of the accident or during transport to a hospital also may not be accounted for completely in data collection for TBI epidemiologic studies. Men are approximately twice as likely as women to sustain a TBI. ${ }^{21}$ This ratio approaches parity as age increases because of the increased likelihood of TBI caused by falls, for which males and females have similar risks in later life. The male-to-female mortality rate for TBI is 3.4:1. ${ }^{21}$ However the cause-specific ratio for firearm-related injuries is $6: 1$, while that for injuries related to MVAs (motor vehicle accidents) is 2.3:1. In Bangladesh, from this study men are approximately five times as likely as women to sustain a TBI. The maleto-female ratio for TBI is $5.25: 1$. This study is dissimilar to Americans study. The risk of suffering a fatal or significant TBI is not randomly distributed within the population. Injury is the leading cause of death among 
Americans younger than 45 years; TBI is the major cause of death related to injury. The risk of TBI peaks when individuals are aged 15-30 years. The risk is highest for individuals aged 15-24 years. ${ }^{21}$ In Bangladesh, from this study the highest risk of individuals between 26 and 35 years of age and second highest of individuals aged 16-25 years which is similar to Americans study. Twenty percent of TBIs occur in the paediatric age group (i.e. birth to $17 \mathrm{yrs})$. The highest mortality rate (32.8 cases per 100,000 people) is found in persons aged $15-24$ years. The mortality rate in patients who are elderly (65yrs or older) is about 31.4 individuals per 100,000 people. A second peak of incidence of TBI is recognized in the elderly age group. After the age of 70 , the incidence again approaches the extreme rate of the young adult. ${ }^{22} \mathrm{~A}$ less pronounced increase risk exist for the infant and very young adult child. In the occupations of the study patients, cultivators $26 \%$ were top of the list and then the laborer $22 \%$, student $14 \%$, house wife and service holder $12 \%$ and businessman was $10 \%$. However, this classification is arbitrary and vague with overlapping among the occupations. In addition the difference is little. Out of total 100 patients $54 \%$ which are most in number were lower class, then $22 \%$ which belongs to lower middle class, then $14 \%$ which belongs to upper middle class and $8 \%$ which belongs to higher class. In this study most of the patients were from lower class 54\%. Most of the study subjects came from rural area. This is may be due to poverty situation of our country. Rich people usually take treatment from private clinic and from private doctors. So they are less in the study. ${ }^{23}$ In this study, speech and language disorder such as dysarthria, aphasia $\&$ Apraxia were $30 \%$ due to injury to cerebellum and unconsciousness. Gait disorder was $86 \%$ due to sensory impaired $54 \%$ and motor impaired $32 \%$. Fracture of different bones of the body specially limb fracture $8 \%$ and spinal fracture $12 \%$. Bladder dysfunction is $64 \%$ due to unconsciousness, spinal fracture and rupture of urethra by traumatic brain injury.

\section{Conclusion:}

Traumatic brain injury accounts $40 \%$ of all deaths from acute injuries in the developed country. This percentage is now increasing in developing country like Bangladesh because socioeconomic condition (low class $54 \%$ among the 100 patients) and TRA 48\%. Beside these, awareness and transport barrier and emergency treatment is important. If we try to increase awareness, transferred the patient early in the nearest emergency centre can decrease the morbidly and motility in TBI. So government and private organizations should setup more trauma centre and can augment to decrease the adverse conditions.

\section{References}

1. Amams JH, Doyle D, Ford I, et al. Diffuse axonal injury in head injury: definition, diagnosis and grading. Histopathology 1989; 15: 49-59.

2. Bart JT, Macciocchi SN, Diamond PT. Mild head injury; Current research and clinical issues. In; Rosenthal M, Griffin ER, Kreeutzer JS, te al, eds. Philadelphia: FA Davis; 1999: 471-8.

3. Centers for Disease Control and Prevention. Traumatic brain injury in the United States: a report to congress. Atlanta: CDC; 1999. Online. Available:http//www.cdc.gov/ncipc/pub-rest/ tbicongress.htm.

4. Frankowski RF, Annegers JF, Whitman S. The descriptive epidemiology of head injury in the United States. In: Beeker DP, Povlishock JT, eds. Central nervous system status report. Bethesda: NINCDS; 1985: 33-43.

5. Frankowski RF, The demography of head injury in the United States. In: Miner M, Wagner KA, eds. Neurotrauma, vol 1.Boston: Butterworths; 1986: 1-17.

6. Kraus JF, McArthur DI, Seilverman TA. et al. Epidemiology of brain injury In: Narayan RK, Wilberger JR Jr, Povlinshock JT, eds. Neurotrauma. New Your: McG raw-Hill; 1996; 13-30.

7. Langlois JA, Rutland-Brown W, Thomas KE. Traumatic brain injury in the United States. Emergency department visits, hospitalizations and deaths. Atlanta: Centers for Disease Control and Prevention; 2004.

8. Sorenson SB, Kraus JF. Occurrence, severity and outcomes of brain injury. J Head Trauma Rehabil 1991; 6(2): 1-10.

9. Coonley-Hoganson R, Sachs N, Desai BT, et al. Seqoelae associated with head injuries in patients who were not hospitalized: a follow-up servey. Neurosurgery 1984; 14: 315-7.

10. Sosin DM, Sniezek JE, Thurman DJ. Incidence of mild and moderate brain injury In the United States: 1991, Brain Inj 1996; 10: 47-54. 
11. Blumbergs PG, Scott G, Manavis J, et al. Topography of axonal injury as defined by amyloid precursor protein and the sector scoring method in mild and severe closed head injury. J Neurotrauma 1995; 12: 565-72.

12. Tieves KS, Yang H, Layde PM. The epidemiology of traumatic brain injury in Wisconsin, 2001. WMJ. 2005; 104(2): 22-5, 54.

13. Corrigan JD, Bogner JA, Lam-Hart GL. Substance abuse and brain injury. In: Rosenthams M, Griffin ER, Kreutzer JS, et al, eds. Rehabilitation of the adult and child with traumatic brain injury, 3rd edn. Philadelphia: FA Davis; 1999: 556-71.

14. Kraus JF, McArthur DI. Incidence and prevalence of and costs associated with traumatic brain injury. In: Rosental M, Griffin ER, Kreutzer JS, et al, eds. Rehabilitation of the adult and child with traumatic brain injury. $3^{\text {rd }}$ edn. Philadelphia: FA Davis; 1999; 3-18.

15. Kraus JF, Sorenson SB. Epidemiology. In: Silver JM, Yudofsky SC, Hales RE, eds. Neuropsychiatry of traumatic brain injury. Washington: American Psychiatry Press; 1994: 3-41.

16. Kraus JF, Black MA, Hessol N, et al. The incidence of acute brain injury and serious Impairment in a defined population. Am J Epidemiol 1984; 119: 186-201.
17. Levin HS, Williams D, Crofford MJ, et al. Relationship of depth of brain lesions to Consciousness and outcome after closed head injury, J Neurosurg 1988; 69: 861-4.

18. Ommaya AK, Gennarelli TA. Cerebral concussion and traumatic unconsciousness: Correlation of experimental and clinic observation on blunt head injuries. Brain 1974; 97: 633-54.

19. Teasdale G, Jennett B. Assessment of coma and impaired consciousness. Lancet 1974; 2:81-84.

20. Choi SC. Predicting outcome in the head-injured patient. In: Narayan RK, Wilberger JE, Povlishock JT, eds. Neurotrauma. New Youk: McGraw-Hill; 1996: 593-611.

21. Kraus JF, Black MA, Hessol N, et al. The incidence of acute brain injury and serious impairment in a de3fined population. Am J Epidemiol. 1984; 119(2): 186-201.

22. Annegers JF, The epidemiology of head trauma in children. In: Shapiro K, ed. Paediatric head trauma. Mt. Kisco: Futura; 1983.

23. Rahman $\mathbf{M}$, et al. Maternal nutritional status as a determent of child health. J Trop Paediatr 1993; 39: 89-90. 